\title{
GCU
}

Glasgow Caledonian

University

University for the Common Good

\section{A review of daylighting design and implementation in buildings}

\section{Wong, Ing Liang}

\section{Published in:}

Renewable and Sustainable Energy Reviews

DOI:

10.1016/j.rser.2017.03.061

Publication date:

2017

Document Version

Author accepted manuscript

Link to publication in ResearchOnline

Citation for published version (Harvard):

Wong, IL 2017, 'A review of daylighting design and implementation in buildings', Renewable and Sustainable Energy Reviews, vol. 74, pp. 959-968. https://doi.org/10.1016/j.rser.2017.03.061

\section{General rights}

Copyright and moral rights for the publications made accessible in the public portal are retained by the authors and/or other copyright owners and it is a condition of accessing publications that users recognise and abide by the legal requirements associated with these rights.

Take down policy

If you believe that this document breaches copyright please view our takedown policy at https://edshare.gcu.ac.uk/id/eprint/5179 for details of how to contact us. 


\title{
A REVIEW OF DAYLIGHTING DESIGN AND IMPLEMENTATION IN BUILDINGS
}

\author{
Ing Liang Wong* \\ School of Engineering and Built Environment, Glasgow Caledonian University, 70 Cowcaddens Road, \\ Glasgow, G4 OBA, UK
}

\begin{abstract}
Daylighting design has become prevalent in modern buildings in the effort to create a more sustainable living environment. Past and recent bodies of research emerged are mainly focused on the different methods of predicting and measuring daylight level and various range of daylighting technologies available. Despite a wide range of developed and commercially available daylighting systems have been reported, their applications have been limited by a lack of studies on their utilisations and high initial costs. Computer simulations have been frequently used in the past to investigate daylighting performance due to reliable and accurate predictions. However, additional simulation time and variable level of skills and knowledge required are major drawback of computer simulations. This paper includes and pools information on all major daylighting design topic in the built environment. The study critically reviews and compares daylighting design principles, strengths and weaknesses of different range of daylighting systems and calculation methods, such as, scale model with artificial sky, full scale model for field measurement, numerical modelling and manual calculation procedures with the aid of diagrams or tables. Such information could be of useful for engineers, researchers and designers to assess the suitability of applying these systems and technologies in different building types and examine the potential of energy and cost savings.
\end{abstract}

Keywords: daylight, daylight factor, glazing, daylighting system, window, skylight

\section{Introduction}

The sun is the biggest source of light and energy on earth and the light we received today comes from the sun in two ways: either directly as sunlight, or modified and redistributed by the atmosphere as diffuse skylight. The light from the sun not only enables us to see, but provides energy and power to the whole ecosystem on earth. The combination of the direct sunlight and the diffuse skylight can be defined as daylight [1]. The quality and intensity of daylight vary according to geographical latitude, season in a year, time of day, local weather, sky conditions, and building geometry. In the UK, the availability of daylight is crucial as we cannot rely on direct sunlight alone for lighting the interiors of buildings [2]. Despite artificial lighting has long being used to supplement lighting in the interiors of buildings, reports suggest negative effect of artificial

*Tel: ++44-01413313864; Email addresses: IngLiang.Wong@gcu.ac.uk, xijiayu@hotmail.com 
lighting on health [3-8]. Using natural light, it can help to maintain a good health, cure some of the medical ailments [9], and reduce psychological sadness related to the Seasonal Affective Disorder [10,11]. Compared to artificial light, daylight offers better conditions for seeing as it contains consistent alterations of intensity, direction and spectral composition; thus, it brings positive implication biologically and physiologically to all living things on earth [12], such as, as natural means for human body to produce vitamin D [11] and hormone [13]. The advantages of daylighting designs and applications in the built environment have been largely documented. Despite various methods used to measure and predict daylighting performance have been reported in the past, most daylighting technologies and methods used are tailor-made or designed for specific cases only. By contrast, this paper includes and pools information from different literature sources and databases (such as, Elsevier, Taylors and Francis, and Springer), compares different methods and strategies for predicting or measuring daylight level, and examines the strengths and weaknesses of different daylighting technologies. Such information would be of useful for engineers, researchers and designers to assess the suitability of applying these systems and technologies in different building types and examine the potential of energy and cost savings.

\section{Daylighting as an alternative to artificial lighting}

Artificial lighting contributes to significant carbon emissions and as a result, leads to global warming. Literature revealed that electric lighting consumes up to $40 \%$ of the annual building energy consumption [14,15], 20 to $30 \%$ of the total energy use in commercial buildings [16], one third of the electricity bill [17] or $35 \%$ of the total electric load in conventional office buildings [13]. In built environment, we benefit from solar energy in various ways, such as, heating and lighting. Passive solar energy design in buildings, which uses building elements for collecting, storing and distributing solar energy, is becoming important. Space heating and daylighting are the most direct and efficient way of passive solar energy design approach. Daylighting, which is an important strategy in modern architecture by which natural light can be brought into a room via building opening to replace or supplement artificial lighting, can contribute to the reduction of the building energy consumption and enhance visual comfort [18-20]. The exploitation of daylight has been recognised as a valuable means of achieving energy efficiency in buildings and improving visual quality of interior building spaces. Previous studies indicated that, by employing daylighting, reduction of 223 million tonnes of $\mathrm{CO}_{2}$ emissions [21,22] or 24000MW of energy demand [23] could be achieved. However, excessive daylight exposure could cause glare, overheating problems and thermal discomfort to building occupants. Surveys show that, the luminous comfort of building occupants is affected by the quality of daylighting $[24,25]$. The benefits of daylighting can only be realised if visual needs and comfort criteria are 
carefully considered in building design [26]. Duncan and Hawkes [27] discussed passive solar energy design for non-domestic buildings, highlighting the importance of lighting energy consumption in non-domestic buildings and the potential of daylight for meeting lighting demands. The opportunities for exploiting daylight in non-domestic buildings have been examined, as well as the factors that needed to be considered if exploitation of daylight was to be successful [24]. Methods and guidance for good daylighting design have also been discussed, which include examples, explanations and practical exercises of how daylight can be successfully used in a variety of building types [28,29].

Daylight in a building does not by itself lead to energy saving. Daylighting can only contribute to cost and energy savings if lighting control strategies or photo sensors can be integrated to dim or switch off artificial lighting when sufficient daylight is available. The use of various control strategies, such as, manual, timed and automatic lighting controls has also been explored. Building Research Establishment (BRE) [30] and Chartered Institution of Building Services Engineers (CIBSE) [31] provided guidance on different types of lighting control suitable for various types of installation. Despite lighting energy savings and subsequent payback period as a result of lighting control application are difficult to assess [32,33], potential energy savings for different types of daylight responsive dimming technologies can be accurately predicted using computer software and validated by field measurements [33-35]. Reduction of artificial lighting energy inside building spaces using lighting controls was revealed in studies [34]. For examples, annual lighting energy savings of more than $5000 \mathrm{kWh}$ [35] were predicted for a high-rise building or up to 41.5\% [19] for a large space industrial building. However, lack of simplified evaluation tools, which are capable of providing information on the suitability and the cost-effectiveness of daylighting, can still be considered as one of the main reasons why building professionals are reluctant to incorporate daylighting features in their design [34].

3. Measurements, estimation and predictions of daylight performance

It is difficult to characterise indoor daylighting because of the numerous design parameters that have to be considered, such as, view factor, aperture size and room depth [36]. Nevertheless, experiments, numerical studies and simplified procedures are common methods used to determine interior illuminance. In early 1980s, BRE had developed simplified procedures to characterise lighting performance in the interiors of day lit buildings [30]. The amount of daylight inside a room can be measured by comparing it with the total daylight available outside the room. This ratio is called daylight factor (DF), which can be measured in percentage (\%). Two types of DF can be calculated: DF at a given position (Point DF) and DF over a given floor area (Average DF, $\mathrm{DF}_{\mathrm{ave}}$ ). DF can be accurately determined by Eq (1), which is expressed as the ratio of 
indoor daylight illuminance to outdoor daylight illuminance under the standard overcast sky $[2,13,22,28,30,37-41]$

$$
D F=\frac{\text { Indoor illuminance from daylight }}{\text { Horizontal unobstructed outdoor illuminance }} \times 100 \%
$$

The value of DF depends on building types, window sizes, frames and position, types of glazing, transmission characteristics of glazing, cleanliness of glazing, and interior room surface reflectance [30]. DF can be measured using scale model with artificial sky [38] or field measurement in a real building [42]. It can also be predicted using computer simulation programs or calculated using simple manual procedures [2]. DF is made up of three principal components: sky component, internally reflected component and externally reflected component $[2,12,28,36,37]$, which can be calculated separately and added together. These components can be calculated using Building Research Station (BRS) daylight table, Waldram Diagram, BRS Daylight Factor Protractors [2], pepperpot diagram [28] or numerical formulas [37]. The resulting DF need to be corrected to allow for deterioration of room reflectances, types of glazing, dirt on glass and the window frame [37]. The calculated DF excludes the effects of building orientation or direct sunlight from both indoor and outdoor illuminance [38,39], whilst the overcast sky on which it is based is very much a worst-case condition.

Point DF can only be used once the window size, shape and position have been decided, which may be too late to alter glazing areas at this stage. It is higher near the openings, but decreases significantly further away from the openings [42]. Compared with Point $\mathrm{DF}, \mathrm{DF}_{\text {ave }}$ is easier to calculate and considerably less dependent on window shape and position, as it can be simply related to glazing area [38]. Derived from Eq (1), $\mathrm{DF}_{\text {ave }}$ is the ratio of average interior illuminance to external global horizontal illuminance under standard overcast sky conditions [38] and can be used to represent the arithmetic mean of DF obtained throughout the room [2]. To date, DF is still the most frequently used parameter to characterise the daylight situation in a building [22]. Almost all national standards and international directives recommend DF as criteria for sufficient daylight quantity assessments [43]. Minimum values of $\mathrm{DF}_{\text {ave }}$ are normally recommended for different building interior spaces, ranging from less than $2 \%$ (artificial lighting dominates daytime appearance) to more than $5 \%$ (fully day lit where daytime artificial lighting rarely needed). Such recommendations have been widely discussed in a number of publication, such as, DETR Good Practice Guide 245, The Code of Practice on daylight (BS 8206 Part 2), CIBSE Window Design Manual and BREEAM $[28,38,44,45]$. $\mathrm{DF}_{\text {ave }}$ can be calculated based on the theory of the split-flux principle that divides 
the flux entering the interior through window over its lower parts of the room surface areas and total internal surface areas [46], which can be determined by Eqs 2 to 5 [13,28,29,36-38,40,47-50].

$$
\begin{aligned}
& D F_{\text {ave }}=\frac{A_{g} \theta T}{A\left(1-R^{2}\right)} \\
& D F_{\text {ave }}=\frac{T M A_{g} \theta}{A\left(1-R^{2}\right)} \\
& D F=D F_{\text {winave }}+D F_{\text {sklave }} \\
& D F=(S C+E R C+I R C+F C) \times M F \times F R \times G L \times M G
\end{aligned}
$$

A variety of aids and methods used for calculating the availability of daylight and the effect of sun shading is shown in Table 1. These mainly refer to indicators developed to quantify the amount of skylight or sunlight reach a window. Majority of these indicators are less suitable and rarely used nowadays since they still involve plotting obstruction from reference points using transparent direction finder and building layout plans with different scales. Such aids and methods have actually posed a difficulty for architects, where Poole [51] has called for the need to standardise calculation method for providing consistent and practical guidance for designers and engineers.

Performance indices other than DF used to assess the daylight performance and availability inside buildings have been discussed, compared and critically analysed [28,29,41,44,49,52]. It was concluded that, DF is the most frequently used indices and widely accepted by international standards, despite improvement has been done by developing other indices $[13,41,43]$. However, one significant weakness of DF is that it is not suitable for direct sunlight calculation and the calculation was highly influenced by building properties [13]. To overcome the limitations of DF for direct sunlight calculation, Vertical to Horizontal illuminance (VH Ratio) has been used as a function of the light decrease on a vertical plane (41,52); while Daylight Autonomy (DA) has been used to measure how a certain illuminance level can be maintained by the use of daylight alone and can be expressed as a percentage of occupied time, either annually or on a month-by-month basis [46].

\begin{tabular}{ll}
\hline Daylight prediction indicators & Assessments \\
\hline Waldram diagram & Vertical sky component \\
BRS daylight factor protractors & Sky component \\
BRS daylight table & Sky component \\
Sun-on-ground indicators & Availability of sunlight on the ground at the equinox \\
Sunlight availability indicators & Probable sunlight hours \\
Skylight indicator & Vertical sky component \\
The no-sky line rule of thumb & Availability of direct light from the sky \\
Sun path indicators & Availability of sunlight at particular times of day and year
\end{tabular}


Table 1 A summary of different methods used to determine the availability of daylight in buildings

Parameters, such as, depth, size and area of a room, window or roof light are critical at the initial design stage and limitations to room parameters were studied. Advice on suitable design and position of windows and rooflights [28], practical guidance on daylighting design and calculations of optimum window size and average daylight factor [46] have been provided for architects at different stages of the RIBA Plan of Work. In order for a room to be successfully day lit, it has been discussed that $\frac{L}{B}+\frac{L}{H}$ must not exceed $\frac{2}{\left(1-R_{b}\right)}$, where $\mathrm{L}$ is depth of room (front to back), B is breadth of room (along the window wall), $\mathrm{H}$ is height of window head above floor level, and $\mathrm{R}_{\mathrm{b}}$ is the average reflectance of surfaces in the half of the room remote from the window $[28,45,49,50,53,54]$.

Apart from room and opening parameters, a wide range of factors, such as, site layout, building orientation and geometry, window parameters, availability of sunlight or skylight, and adjacent obstruction have to be considered and examined carefully in order to effectively apply daylight in a building space $[12,24,28,29,49,55]$. Table 2 summarises these factors in three categories: site layout, building geometry and opening parameters. A useful guidance on how a good site layout planning can contribute to achieving good daylighting and sunlighting in buildings has been provided [29]. It highlights good practice to site layout planning and contains methods to quantify access to sunlight and daylight within a layout.

\begin{tabular}{ll}
\hline Categories & Factors affecting daylight performance \\
\hline Site layout & External obstructions (existing buildings and trees) \\
& Overshadowing \\
& Building orientation \\
& Balconies and overhangs \\
Building geometry & Extension to the existing building, which is perpendicular to window \\
Opening parameters & Window sizes and parameters (height of window head from floor level) \\
& Roof light parameters
\end{tabular}

Table 2 Factors which influent the availability of daylight in buildings

Effective window design is essentially part of energy-conscious building design. BRE Digest 309 can be used to assess visual and energy impacts of window design [2]. It is the simplest method of daylighting design involving alteration to window parameters or glazing type to receive optimum daylight in building spaces $[34,56]$. It is also necessary to consider occupation density, room configuration and building type in order to reach a right balance between daylighting strategies and the climate [57]. Analysis shows changes to façade design and configuration could impact on daylighting performance level in office buildings [58]. Li and coresearchers [45,59] had identified building area and orientations, window area, glass type, shading and external obstruction as five key factors affecting the daylighting performance level of office buildings and 
residential flats in subtropical Hong Kong. Sky conditions, façade orientation, obstruction and transparency ratio of window glazing are other factors affecting daylighting performance [60]. Distance from the adjacent buildings and height of adjacent buildings influence the amount of direct and diffuse daylight reaching the windows as well [11]. Visible sky angle and no-sky line position are two methods used to measure the impact of external obstruction on the amount of daylight received in a room [49,55]. Simulations show significant energy saving by altering building parameters (room and window sizes) and layout as well as implementing electric lighting management [32].

\section{Innovative daylighting systems}

In the last 30 to 40 years, different daylighting technologies have been developed to improve daylighting performance in building interiors. Littlefair and colleagues from BRE have been pioneering the work in developing daylighting design strategies and technologies in buildings [29,54,61]. They have looked that both design and technological approaches, such as, layout and parametric changes to building designs as well as the application of daylight 'harvesting' technologies. Also known as daylighting system, these are actually devices located near or at the openings of building envelope, which can reflect and redirect incoming natural light flux into interiors for improving lighting conditions [1]. Two common types of daylighting systems are side-lighting and top-lighting [22,62]. Conventional vertical window opening is a common example of sidelighting; while opening in the roof or ceiling element of buildings is an example of top-lighting. Daylight can be delivered into a building through conventional vertical windows, clerestory windows or rooflights as well as a number of remote distribution systems [31,49]. For a conventional vertical window, light levels drop off rapidly when the distance from the window increases. The greater the depth of a room, the poorer it is illuminated by daylight [18]. Al-Obaidi and Rahman [63] critically investigate optimum design requirements of top-lighting system, which conclude that system type, sky condition and human comfort are significant factors. Designs with top-lighting must be examined carefully as potential overheating resulting from inappropriate top-lighting design should also be avoided [22,64]. To minimise this problem, innovative daylighting systems, which contain new components and technologies, have been developed to bring sunlight deeper into building interiors; whilst reducing overheating problem [65]. Littlefair [61] discussed more than 30 types of innovative daylighting systems, which can be divided into two categories: light guiding system (LGS) and light transporting system (LTS). LGS and LTS sometimes also referred to fenestration and core systems respectively [66]. LGS is a simpler daylighting system which can reflect and direct sunlight to the back of a room, where least sunlight can be received. LTS is more complex, which can collect, transport and distribute sunlight to inner zone in a commercial building with no access to wall or roof opening. The 
daylighting strategy in this type of building involves daylight penetration, distribution, protection and control [57]. Both types of the daylighting systems can be used to improve daylight distribution in building space and to control direct sunlight [54]. Despite previous research to improve natural illumination within buildings, particularly, the deep floor plan buildings with minimum daylight penetration, it has been focused mostly on office buildings, not industrial buildings, where lighting is a major electricity consumer [19].

\subsection{Light Guiding Systems}

Simple and inexpensive modification of window glazing and shading devices was able to significantly improve daylighting quantity and quality for visual comfort [67]. Conventional sun-shading devices, such as, solar screens [68], roller blinds and venetian blinds [69] are commonly used in buildings because they are relatively inexpensive and easy to use [70,71]. However, these conventional devices block out natural light and reduce amount of light penetrating into buildings, which would affect the light distribution in the buildings [12]. Compared to these conventional devices, more advanced devices, such as, LGS have been developed to reduce excessive solar gain without reducing the transmission of diffuse skylight. LGS are simple and easy-to-apply technologies developed to reflect, refract or deflect sunbeams from exterior into interiors with room depth of less than $10 \mathrm{~m}$ from the building facades. LGS can be integrated into existing windows or roof lights to modify or supplement them [61], improve light distribution in the room as well as reduce glare and overheating that may occur adjacent to window opening. Excessive incoming solar radiations that reach the interiors adjacent to windows can be reflected and redirected by LGS to the ceiling and redistributed within the room.

Light shelves [12,24,54,61,67,69,72-85], fixed louvres [61,69,84], light directing louvres or glass [11,84], and light guiding shade [86] are some examples of LGS, which can be mounted at the upper part of a typical window to provide solar shading and glare control to occupants adjacent to the window, while allowing daylight into the room. These systems, which can be fitted either internally or externally, increase core illuminances under certain well defined conditions when the sun shines onto the windows for a particular season of the year [61]. Another line of development has been the curved slat profiles [61,69,74,78], variable angle configured slats [87], compound parabolic concentrating (CPC) reflective window blind system [88], highly reflective lamellas with retro-reflection [11], anidolic solar blind [89], and semi-transparent acrylic profiles [90]. These systems can be applied inside double glazed units and have been developed to deal with different incidence angles with minimum maintenance requirement. Adjustable or flexible systems that can be used to track the sunlight at different angles, such as, blinds with different slat angles $[67,71,91,92]$, reflective, mirrored or translucent louvres [11,24,54,61,69,70,80], reflective window sills [61], combined 
prismatic louvre and reflective blind system [11,70], holographic films on movable louvres [80], movable louvre variable-area light-reflecting assembly (VALRA) system [93], transparent shading device [94], and sun-tracking prismatic system [95] were also discussed. Such configurations are much capable of admitting sunlight more uniformly throughout the room space, compared with the fixed systems. For daylighting systems to be more effective at shading and redirecting light, supplementary shading devices may be required, but it will increase cost and reduce light input [80]. Transparent insulated materials [18,96-104], prismatic films $[24,54,61,69,74,76,78,80,84,105]$, holographic films [61,80], laser-cut light deflecting panel (LCP) $[61,64,84,86,106-109]$, and phase change material (PCM) [110] are more advanced technologies that can be applied to window glazing, without the need of having supplementary shading devices. These systems can also be used as sun shading devices by controlling sunlight through reflection; while allowing sunlight through from specific angles [80] or combine usage of solar radiation and thermal qualities [18]. The practicality of some of these systems however, depends on the adaptation of the building façade to the system tilted at certain angle only. For example, laser cut light deflecting panels perform best at angle from $20^{\circ}$ to $40^{\circ}$ [109]. A new type of solar and light control device with retro-reflecting slats can select and direct solar radiation, avoiding direct radiation and glare discomfort and up to 70\% daylighting autonomy [111].

Innovative types of skylights installed on the building roofs were presented and can be categorized into active and passive skylight [112]. Active skylights contain mechanical components with the ability of tracking the azimuth path of the sun; while passive skylights are less complex with no tracking system. Common types of skylights include shed-type rooflight [113], skylight contained glass, sunscreen and light-directing layer [114], skylights made of several glazing systems [115], skylight with prismatic glazing [61], toplight systems with various shapes [116], rooflight made of glass, thermoplastic or glass reinforced polyster [117], and optimized lightscoop skylight with a curved shape reflector $[61,118]$. Studies show an increase of between $5 \%$ and $10 \%$ in DF for shed-type rooflight or lightscoop skylight [118]. A higher level of useful daylight illuminance could be achieved when a rooflight to floor area ratio is between 0.15 and 0.20 [119]. A rooflight area of up to $20 \%$ of the total building floor area could contribute to more than 1000 lux of illuminance in horizontal plane (117). Reflecting mirrors were also used to reflect and redirect sunlight from the top of a light well into lower floors in a multi-storey building in Japan [120]. Table 3 shows a list of different LGS which have been developed and identified according to the constructions and the types of materials used.

\begin{tabular}{llllllll}
\hline Light Guiding System & $\begin{array}{l}\text { Tilt- } \\
\text { able }\end{array}$ & $\begin{array}{l}\text { Solar } \\
\text { shading }\end{array}$ & Ease of application & $\begin{array}{l}\text { Ease } \\
\text { maintenance }\end{array}$ & $\begin{array}{l}\text { Thermal } \\
\text { reduction }\end{array}$ & $\begin{array}{l}\text { Allow } \\
\text { view }\end{array}$ \\
\hline Light guiding shade & No & Yes & Window & Easy & Yes & Yes \\
Reflective blinds & Yes & Yes & Window & Easy & Yes & Limited \\
Venetian blinds & Yes & Yes & Window & Easy & Yes & Limited \\
Movable blinds & Yes & Yes & Window & Easy & Yes & Limited
\end{tabular}




\begin{tabular}{lllllll} 
Light shelves & No & Yes & Window & Easy & Yes & Yes \\
Prismatic louvers & Yes & Potential & Window & Easy & Yes & Limited \\
Mirror systems & No & Yes & Fixed louvre & Difficult & Yes & Limited \\
Prismatic glazing & No & Potential & Window \& roof & Difficult & Yes & Limited \\
Translucent louvers & Yes & Yes & Window & Difficult & Yes & Limited \\
Transparent insulated glazing & No & Potential & Inside double glazing & Easy & Potential & Limited \\
Toplight on roof & No & No & Roof & Difficult & Potential & Limited \\
Solar screens & No & Yes & Window & Difficult & Yes & Limited \\
Skylight on roof & No & No & Roof & Difficult & Potential & Limited \\
Lightscoop skylight & No & No & Roof & Difficult & Potential & Limited \\
Shed-type rooflight & No & No & Roof & Difficult & Potential & Yes \\
Holographic films & No & Yes & Inside double glazing & Easy & Potential & Yes \\
Active modular glazing panel & No & Yes & Window & Easy & Yes & Yes \\
Three-layered rooflight & No & No & Roof & Difficult & Potential & Limited \\
Façade panels with PCM & No & Potential & Inside double glazing & Easy & Potential & Limited \\
\hline
\end{tabular}

Table 3 Strengths and weaknesses of light guiding systems presented by previous researchers

\subsection{Light Transporting Systems (LTS)}

It is increasingly difficult to provide required daylight for daily activities using LGS alone due to increase in building density and complexity of internal building layout [121]. More advanced daylighting technologies, such as, LTS, can be used for transporting and distributing daylight. LTS offer opportunities for reliable daylight into core zones of multi-storey buildings [122]. In contrast to LGS, LTS can be applied to rooms with the depth of more than $10 \mathrm{~m}$, as the systems collect, redirect, transport and distribute the daylight into the space of the rooms. Light pipes and anidolic daylighting systems are examples of LTS. A light pipe is also known as light duct [123] or tubular daylighting device $[112,124]$ and can be used to collect sunlight directly from building façade, transferred to the core zones in the building optically by a series of mirrors inside the pipe. Two types of light pipes are reported: vertical and horizontal light pipes $[24,54,61,76,81,85,86,123,125-$ 130]. The light pipe acts as transmission network [122] and guides the collected light beams, either several stories vertically down the building with light distribution system on each floor; or through building fabric or ceiling horizontally into interior zones without access to window opening. Despite light pipes may be capable of spanning distances of greater than 30m within buildings, they are limited in their applicability due to the pipe diameters, which cannot generally be more than 20 times smaller than their length [131].

Different light pipes available commercially in the market are manufactured by Monodraught Ltd, Solatube International Inc., Velux, and Doel Corp and have different characteristics and applications [122]. Table 4 shows the existing innovative type of LTS, developed and manufactured using different technologies. The performance of different light pipes installed in a test room and a living room was evaluated and the results show the light pipes can provide visual comfort and energy saving if carefully designed [122]. When the solar elevation was low, light pipe performance decreases due to multiple reflection losses within the pipes [86]. Heliostat tracking system, which tracks, collects and concentrates solar radiations with lenses or mirrors 
[11,54,61,76,84], CPC trough and linear Fresnel lens [132] and primary parabolic collector [10], which capture and concentrate sunlight, can be applied to the aperture of light pipes to enhance the sunlight collection. More sophisticated materials, such as, fibre optics, solid acrylic, microprisms, metal tube, hollow mirrored or prismatic pipes, mirrored pipe coupled with deflecting sheet, and silvered aluminium sheet with $95 \%$ reflectivity were used as advanced light pipes to enhance the light distribution $[10,76,84,123,124,126,128,130,132,133]$. Shao and Callow presented light rods of small diameter and can be bended by up to $90^{\circ}$, which have higher transmittance than light pipes of similar aspect ratios [131]. Sedki and Maaroufi developed Polymethylmethacrylate (PMMA) fibre optic wires with dimension of not more than $3 \mathrm{~mm}$ used inside a light pipe together with a parabolic solar concentrator for effective light collection and reflection to provide illumination to underground basement [134]. Despite its cost effectiveness and reliability of providing high level of illumination, the performance of the system was limited by issues, such as, melting of PMMA in high temperature. Francini and colleagues developed a prism light guide structure, which was as reliable as light pipe with fibre optics, but cheaper (124).

\begin{tabular}{|c|c|c|c|c|}
\hline Innovative daylighting system & Manufacturers & Countries & $\mathbf{C} / \mathbf{D} / \mathbf{P}$ & Installation \\
\hline Heliostat and sun pipes systems & Heliobus & Switzerland & $\mathrm{C}$ & 1995 \\
\hline Heliostat with an ultra-sunlight concentrator & Sunportal & South Korea & $\mathrm{C}$ & 2012 \\
\hline Heliostat with light guide with prismatic materials & Arthelio & Germany & $\mathrm{D}$ & 1998 \\
\hline \multirow[t]{2}{*}{ Fresnel lenses and fibre optic } & Himawari & Japan & $\mathrm{C}$ & Early 1970 s \\
\hline & Parans & Sweden & $\mathrm{C}$ & 2004 \\
\hline Fresnel lenses and light pipe & Hybrid Solar Lighting & USA & $\mathrm{D}$ & 2013 \\
\hline Fresnel lenses and liquid light guide (Solux) & Bomin Solar Research & Germany & $\mathrm{P}$ & 2001 \\
\hline Skylight with mirrors and light duct & Sundolier & USA & $\mathrm{C}$ & 2004 \\
\hline \multirow[t]{3}{*}{ Skylight with curved mirrors } & SunCentral & Canada & $\mathrm{C}$ & 2013 \\
\hline & Solar Canopy & Canada & $\mathrm{D}$ & 2010 \\
\hline & Illuminance System & & & \\
\hline Heliostat with Fresnel lenses and light guide & EC Energy & EU & $\mathrm{P}$ & 2002 \\
\hline (Universal Fibre Optics project) & Programme & & & \\
\hline Parabolic concentrators and horizontal light guides & ADASY & $\begin{array}{l}\text { European } \\
\text { EUREKA }\end{array}$ & $\mathrm{P}$ & 2012 \\
\hline Sun pipe with dome & Solatube & International & $\mathrm{C}$ & 1987 \\
\hline Anidolic ceiling system & LESO-PB & Switzerland & $\mathrm{P}$ & 1990 \\
\hline Sun pipe, sun catcher & Monodraught & UK & $\mathrm{C}$ & 1995 \\
\hline Sun tunnel systems with dome and rectangular pipes & Velux & Denmark & $\mathrm{C}$ & 2005 \\
\hline Solarspot with dome and mirrored hollow light pipes & Syneco & UK & $\mathrm{C}$ & unavailable \\
\hline
\end{tabular}

Table 4 A summary of commercialized (C), demonstrated (D) and prototyped (P) light piping systems

The concentrated light transported along the light pipes, is then distributed into the interior building zones by means of special luminaires or emitters, such as, specialised triangular arrangement of LCP [135] or transparent light tubes [11]. Anidolic daylighting system, which is a shorter version of light pipe, contained curved daylight collectors, were constructed using the principles of CPC to enhance the daylight collection and distribution [89,136-139]. The systems comprised of light ducts integrated into ceilings for guiding daylight into building space and can achieve a DF of more than $3 \%$ at a point up to $6 \mathrm{~m}$ from building façade 
[137]. Anidolic daylighting system with its light pipe made of high reflective plastic and mirror coating could provide illumination to rooms of $40 \mathrm{~m}^{2}$ [140]. The integration of anidolic daylighting system and electrochromic glazing in building façade can achieve optimal control of the daylight flux in an office room [141].

Although a large number of daylighting systems are available in the building industry today, their usage is limited for reasons, such as, high initial cost, maintenance and variability in their performance parameters. In most cases, the systems are also tailor-made, require detailed design and only used in some high profile projects for marketing, where cost is irrelevant [66]. A summary of strengths and weaknesses of both LGS and LTS is shown in Table 5. Beltran and colleagues [85] compared the performance of light shelves and light pipes, where they concluded that light pipes are more efficient than light shelves. Despite the overall aperture area of best shelf design was approximately the same as light pipe aperture $\left(1.1 \mathrm{~m}^{2}\right)$, light pipes had more than twice the reflective surface area of the light shelves. Light pipes can achieve seven hours of work plane illuminance of more than 200lux per day, compared to four hours for light shelves [85]. Light pipes however, are expensive, requires maintenance [61] and the performance can be constrained by overcast sky conditions and changeable solar altitudes. Despite light pipes cannot be properly used to substitute windows due to changeable weather conditions, the light pipes can present electricity energy saving alternatives for permanent artificial lighted rooms in buildings, such as, in windowless zones [142].

\begin{tabular}{lll}
\hline Daylighting system & Strengths & Weaknesses \\
\hline $\begin{array}{l}\text { Light guiding } \\
\text { system }\end{array}$ & $\begin{array}{l}\text { Easier to implement and apply to window } \\
\text { opening; } \\
\text { Easier to maintain; } \\
\text { Cheaper compared to LTS }\end{array}$ & $\begin{array}{l}\text { Lower efficiency compared to LTG [85]; } \\
\text { Practicality depends on tiltable angle of } \\
\text { system [109]; } \\
\text { Subject to external obstruction; } \\
\text { Potential view obstruction; } \\
\text { Some LGS may require high demand of user } \\
\text { participation [90] }\end{array}$ \\
& & $\begin{array}{l}\text { Expensive and require modification to } \\
\text { building interior [61,124]; }\end{array}$ \\
Light transporting \\
system & $\begin{array}{l}\text { Higher efficiency with longer hour of } \\
\text { workplane illuminance [85]; } \\
\text { Minimum external obstruction; } \\
\text { Applicable to buildings with complicated } \\
\text { design }\end{array}$ & $\begin{array}{l}\text { Performance constrained by overcast sky } \\
\text { conditions and changeable solar altitudes; } \\
\text { Light leakage from roof penetration [143] }\end{array}$ \\
\hline
\end{tabular}

Table 5 A summary of strengths and weaknesses of both light guiding and transporting systems

5. Methods of investigating daylighting in buildings

The daylighting performance of buildings can be assessed using various methods, ranging from manual design tools with simple charts to more sophisticated computer-based design tools. Approximately 50 methods were identified ranging from those which were solely manual to those requiring mainframe computers for implementation [24]. Various methods on daylighting predictions discussed in the past are scale building models with simulators $[44,49,116,144]$, mathematical or analytical modelling $[71,91,126,145$ - 
149], full scale models or mock-ups for field measurement $[19,35,37,49,67,71,91,92,111,115,141]$ and computer simulation software $[18,19,23,26,33,35,37,46,49,59,67,68,91,92,111,115 ; 116,118,132,141,149$ -

156]. Table 6 shows the strengths and weaknesses of these methods as reported in literature. Among all methods discussed, full scale models or mock-ups are most costly to implement due to degree of difficulty in façade configurations and technological integration. Despite the process is usually time-consuming, the results are often realiable and practical as it involves actual technologies and materials in the real sky conditions [49]. Scale models are smaller version of building models, which are usually built in desired scales and similar to architectural models. The benefits of scale models are that, they are easier and cheaper to build and the models are easily made and handled [49]. However, the difficulty of building a daylight scale model is not less than building a traditional architectural model. Certain rules and considerations, such as, geometry, elimination of light leaks, material choice and inclusion of furniture in models, etc. need to be carefully integrated when building a daylighting model in order to obtain results that are as accurate as possible (157).

\begin{tabular}{|c|c|c|}
\hline Methods & Strengths & Weaknesses \\
\hline Scale models & $\begin{array}{l}\text { Visualize daylight performance; } \\
\text { Assist decision-making process for appropriate } \\
\text { design option [49]; } \\
\text { Built in desired scales; } \\
\text { Studies can be undertaken using artificial sky } \\
\text { to represent a specific time, date and latitude } \\
\text { [49]; } \\
\text { Built at all design stages [49]; } \\
\text { Easier and cheaper than real building; } \\
\text { Models can be created and handled easily [49]; } \\
\text { Apply sensors/ camera inside model; } \\
\text { Façade configurations and geometrical changes } \\
\text { can be easily made [49] }\end{array}$ & $\begin{array}{l}\text { Rules and considerations in model building } \\
\text { [157]; } \\
\text { Over-estimated illumination [13]; } \\
\text { Issues with sky simulators [13] }\end{array}$ \\
\hline $\begin{array}{l}\text { Mathematical } \\
\text { models }\end{array}$ & $\begin{array}{l}\text { Easier and quick to calculate even without } \\
\text { specific design details (eg. average DF) }\end{array}$ & $\begin{array}{l}\text { Accuracy needs to be validated and tested } \\
\text { compared to experiments }\end{array}$ \\
\hline $\begin{array}{l}\text { Full scale } \\
\text { models/ mock- } \\
\text { ups }\end{array}$ & $\begin{array}{l}\text { Visualize daylight performance in true sky } \\
\text { conditions; } \\
\text { True representation of actual design [49]; } \\
\text { Real building and systems under real sky } \\
\text { conditions; } \\
\text { Ability to use real and accurate materials } \\
\text { within buildings [49]; } \\
\text { Suitable for complex LGS which cannot be } \\
\text { replicated at scale [49] }\end{array}$ & $\begin{array}{l}\text { Large and expensive [49]; } \\
\text { Difficult, time consuming and costly to } \\
\text { implement technologies; } \\
\text { Façade configurations not easily interchange- } \\
\text { able; } \\
\text { Most assessment limited to real sky conditions } \\
\text { [49]; } \\
\text { Models should be weather-proofed and } \\
\text { orientated correctly if located outdoors [49] }\end{array}$ \\
\hline $\begin{array}{l}\text { Computer } \\
\text { simulations }\end{array}$ & $\begin{array}{l}\text { Cost effective; } \\
\text { User-friendly interface [90]; } \\
\text { Three-dimensional rendering [49]; } \\
\text { Easier analysis with variable parameters and } \\
\text { complex models; } \\
\text { Ability to perform annual simulation [158]; } \\
\text { Provide 'preview' of daylighting effect [90]; } \\
\text { Dynamic visualization, such as sun animations } \\
\text { and time lapse [49] }\end{array}$ & $\begin{array}{l}\text { Speed of software rendering [159]; } \\
\text { Accuracy needs to be validated and tested } \\
\text { compared to experiments [160]; } \\
\text { Calculation errors; } \\
\text { Certain programs require skillful and well- } \\
\text { trained users [13]; } \\
\text { Input quality affects accuracy [156]; } \\
\text { Output needs careful expert interpretation [156] }\end{array}$ \\
\hline
\end{tabular}

Table 6 Strengths and weaknesses of the various methods used to investigate daylight performance 
Building energy simulation programs are valuable tool in the design stage of new buildings to assess potential daylight savings by performing parametric studies of varying windows and shading devices for optimization of building energy performance [154]. Computer simulation programs are effective in offering design support, due to the capability of involving large number of design parameters and performing daylighting performance analysis on detailed and scenario-based cases. Simulations allow accurate comparisons within the levels of experimental uncertainties, provide practical and computationally efficient solutions for energy performance assessment of daylighting applications, and enable the researchers to focus on improving building designs to obtain best results. Survey revealed that, $79 \%$ of the respondents who considered daylighting aspects in their building design had used computer simulations; whilst the use of scale models among daylight specialists has fallen substantially since the use of computer simulation programs can generate more accurate results [161]. Previous studies show that, the simulation results matched well with the results obtained from field measurement, indicating the reliability of the computer software [19].

Despite computer simulation programs was frequently used during the design development stage, the complexity of the programs and insufficient program documentation have been identified as weaknesses of the existing computer simulation programs. Such level of complexity increases the amount of time required for calculations and only those with reasonable skills and knowledge would be able to perform the calculations. Daylight simulation developer community is still very fragmented with approximately 42 daylight simulation programs have been used [161]. One of the earliest issues with daylight simulation software was the problems of interface and creation of models due to the speed of rendering software [159]. However, with the advance in simulation technology, most commonly used lighting simulation programs today have photo-realistic rendering programs, which could inform on how the actual building might perform [13]. Improvement to shortcomings of the lighting simulation regarding accuracy, calculation of few parameters, long computational times, simple scenarios and disconnection from whole building simulation has been reported [156]. Minimum accuracy between measurements and simulation was reported as around $20 \%$ and one of the main difficulties is how to acquire reliable measurements of reflectivity from surroundings. Integration of lighting simulation within whole-building simulation is still under development. Progress is needed for the complexity required in lighting simulation to be useful in energy calculations [156].

Works to develop user-friendly programs to enhance daylighting simulations have been reported. Kota et al. [152] discussed the integration of Building Information Modeling (BIM) tool with daylighting simulation programs, such as, RADIANCE, DAYSIM, ADELINE, and Ecotect for easier file input and to reduce the 
need for the tools to define building geometry in a three dimensional (3D) coordinate system. Other integrated simulation programs, such as, Relux, LighTools, SolidWorks, Lightscape, Microstation, RadioRay and DIALux were also used to provide 3D view of building models [42,132,159]. Fakra et al. [36] developed a new model to introduce simulation code into CODYRUN software, which was simple, user-friendly and can reduce calculation time. Gagne et al. [150] and Andersen et al. [26] combined fuzzy rule-based system with a simulation program, Lightsolve, to develop an interactive expert system for providing design guidance in improving daylighting performance in the early design stage. While every simulation tool is unique and has its own limitation, most researchers had either integrated different simulation tools, used more than one simulation tools to perform daylighting studies for better results, or compared them with experimental or measured results for validation [19,68,92,111,115,149,153,154]. Daylighting and thermal simulation programs were integrated to evaluate the impact of lighting energy savings on global building energy consumption $[18,33]$, where a $50 \%$ to $80 \%$ reduction to artificial lighting energy consumption was reported [33]. Table 7 shows various daylighting computer simulation tools used in the past, in which RADIANCE, ADELINE, Ecotect, DOE, EnergyPlus, and DAYSIM are the most frequently used simulation programs.

\begin{tabular}{|c|c|c|}
\hline Programs/ tools & Assessment & References \\
\hline Dialux & Prediction of daylight illuminance & [91] \\
\hline Lightsolve & Provide design guidance to users to improve daylighting performance & {$[26,150]$} \\
\hline RADIANCE & Ray-tracing lighting simulation for UNIX computers & $\begin{array}{l}{[11,18,19,46,67,68,95} \\
111,115,116,141,142,1 \\
53,155,162]\end{array}$ \\
\hline $\begin{array}{l}\text { ADELINE } \\
\text { (Superlink/ } \\
\text { Radlink/ Superlite) }\end{array}$ & $\begin{array}{l}\text { 3D simulation program to evaluate the potential lighting energy } \\
\text { savings of replacing artificial lighting with daylighting }\end{array}$ & {$[32,92,115]$} \\
\hline Ecotect & $\begin{array}{l}\text { Evaluate the performance of solar and lighting control devices, as } \\
\text { well as daylighting performance of possible building orientations and } \\
\text { shading strategies }\end{array}$ & {$[19,111,142,153]$} \\
\hline CODYRUN & Indoor daylighting value calculation & {$[36]$} \\
\hline DAYSIM 3.0 & Evaluate daylight conditions in a building & {$[11,19,68,151,160,162]$} \\
\hline DOE-2.1 & Simulate energy performance of daylighting control systems & {$[34,154,164]$} \\
\hline Photopia & $\begin{array}{l}\text { Accurate prediction of performance of light pipes compared to } \\
\text { analytical method }\end{array}$ & [149] \\
\hline $\begin{array}{l}\text { BIM-based } \\
\text { simulation tool }\end{array}$ & $\begin{array}{l}\text { Development and validation of a prototype to integrate Revit with } \\
\text { RADIANCE and DAYSIM }\end{array}$ & {$[152]$} \\
\hline EnergyPlus & $\begin{array}{l}\text { Model daylighting performance of a high-rise residential building } \\
\text { with severe sky obstruction }\end{array}$ & {$[59,154,160]$} \\
\hline $\begin{array}{l}\text { LightTools/ } \\
\text { SolidWorks }\end{array}$ & Creation of 3D models to simulate fibre optical daylighting system & {$[132]$} \\
\hline IES VE (6.1.1) & $\begin{array}{l}\text { Analysis covers solar, energy, lighting data, cost and value, egress, } \\
\text { computational fluid dynamics and mechanical parameters }\end{array}$ & {$[40,149]$} \\
\hline Relux & Creation of 3D model to calculate DF & [42] \\
\hline SkyCalc & Daylight calculation of photocontrols with skylighting & [23] \\
\hline Autodesk VIZ 4 & Daylight modelling in ray-tracing and radiosity lighting algorithms & [94] \\
\hline SPOT & Optimizing the placement and orientation of photo sensor & {$[160]$} \\
\hline Lightscape & Creation of 3D model to calculate DF & {$[159]$} \\
\hline RadioRay & Creation of 3D model to calculate DF & {$[159]$} \\
\hline Microstation & Creation of 3D model to calculate DF & [159] \\
\hline
\end{tabular}

Table 7 A summary of various computer simulation programs used to evaluate daylighting performance 
Both computer simulations and measurements offer different possibilities and drawbacks, which vary according to the characteristics of the code or the artificial sky/ sun used [144] and large discrepancies between the real and simulated sky conditions were predicted [116]. It was concluded that the inconclusive experimental results might due to uncertainties related to daylighting system's optical properties, imperfect geometry, accuracy of the simulated sky conditions, and difficulty in comparing measured with simulated data. Further work is needed to remove the uncertainties [149]. Scale modelling can be effectively and accurately used to evaluate the impact of daylighting for a particular case study. Scale building models with various types of shading devices can be easily created and orientated for simulation under different sky conditions and sun positions either using a solar simulator or under a real sky condition $[45,144,157]$. Gagne et al. [150] and Kazanasmaz [91] predicted daylight illuminance with the application of fuzzy logic algorithm, whilst, Kim and Kim [71] used linear regression models to determine the fluctuation range of outdoor daylight illuminance.

\section{Conclusions}

Despite daylight can contribute to occupants' sense of well-being, excessive daylight could pose overheating problem to occupants [44]. It is essential to ensure that effective daylighting control systems are in place to prevent unwanted daylight and thermal discomfort. Daylight can also be properly incorporated into a building to offset the electrical lighting energy consumption using innovative daylighting systems. Despite many innovative daylighting systems are currently available in the market, there is very little information on how or where these daylighting systems can be best utilised [112]. Previous research [163] suggested that, daylighting systems should be tailor-designed and made to suit different circumstances, instead of designing a generic daylighting system which could overcome all challenges at once. This may, however, pose a limitation to the application as each technology is unique and requires the input of specific knowledge and technical expertise. An effective daylighting system should be able to avoid any visual discomfort, which is frequently caused by conventional lighting installations [31]. The main challenges that could prevent their widespread application are high initial costs, utilisation difficulties and application limitations [163]. Among the methods available to study daylight performance, it can be concluded that each has its own strengths and weaknesses, with full scale models being the most effective but also most expensive. With the advance in computer technology, computer-based simulation studies can also offer cost-effective solution and accurate predictions to daylighting performance. The methods are ideal especially at the initial stage of the studies or building design, prior to the application of more expensive real technologies or systems. The simulated results however, have to be validated by experimental or measured results. To increase the accuracy and 
reliability of the simulation studies, it is suggested that a longer measurement periods is recommended to allow rigorous comparison with simulations [149] and more works should be expected in the future to develop more accurate and reliable computer programs.

\section{Nomenclature}

$\mathrm{A}=$ total area of enclosing room surfaces, in $\mathrm{m}^{2}$

$\mathrm{A}_{\mathrm{g}}=$ glazed area of windows (excluding frames or obstruction), in $\mathrm{m}^{2}$

$\mathrm{DF}_{\mathrm{ave}}=$ average daylight factor, in $\%$

$\mathrm{DF}_{\text {winave }}=$ average daylight factor for vertical window, in $\%$

$\mathrm{DF}_{\text {sklave }}=$ average daylight factor for skylight, in \%

ERC $=$ Externally Reflected Component (unitless)

$\mathrm{FC}=$ correction caused by the remoteness of a point illuminated by natural light from an opening (unitless)

$\mathrm{FR}=$ correction factor for window framing (unitless)

$\mathrm{GL}=$ daylight transmission coefficient of the glass (unitless)

IRC $=$ Internally Reflected Component (unitless)

$\mathrm{M}=$ maintenance factor, allowing for the effects of dirt

$\mathrm{MF}=$ correction factor for window dirt (unitless)

$\mathrm{MG}=$ activity coefficient of the study site (unitless)

$\mathrm{R}=$ average reflectance of surrounding room surfaces, area $\mathrm{A}$

$\mathrm{SC}=$ Sky Component (unitless)

$\mathrm{T}=$ transmittance of glass, including the effect of dirt

$\theta=$ angle of visible sky, measured in section from the centre of the window opening, in degree

\section{Acknowledgements}

The author would like to thank the reviewers for constructive comments on the paper.

\section{References}

[1] Baker N, Steemers K. Daylight design of buildings. Earthscan/ James and James; 2002.

[2] BRE. Estimating daylight in buildings: Part 1: An aid to energy efficiency. BRE Digest 309. Bracknell: IHS BRE Press; 1986.

[3] Wiskemann A. Fluorescent lighting enhances tumor formation. Cancer Research and Clinical Oncology 1986. 
[4] Hazell J. Fluorescent lighting contributes to agoraphobia. Psychology and Medicine 1990.

[5] Rea S. Circadian disruption caused by fluorescent light in the built environment contributes to breast cancer and endocrine disruption, Cancer Causes and Control 2001.

[6] Basso Jr, MR. Fluorescent lighting caused increased stress in humans. Journal of Neuroscience 2001.

[7] Brainard GC. Photoreception for regulation of melatonin and the circadian system in humans. In: Fifth International LRO Lighting Research Symposium, Orlando; 2002.

[8] O'Leary. Increase in breast cancer rates among night workers exposed to fluorescent light. American Journal of Epidemiology 2006.

[9] Hraska J. Chronobiological aspects of green buildings daylighting. Renewable Energy 2015; 73: 109-114.

[10] Sapia C. Daylighting in buildings: Developments of sunlight addressing by optical fiber. Solar Energy 2013; 89: 113-121.

[11] Mueller HFO. Chapter 9: Daylighting. In: Sustainability, Energy and Architecture, Elsevier; 2013, p. 227-255, ISBN: 9780123972699.

[12] Pokorny K. Product review. Architects' Journal July 1998; 43-56.

[13] Mardaljevic J. Daylight, Indoor Illumination, and Human Behavior. In: Loftness V., Haase D., editors. Sustainable Built Environments, New York: Springer; 2012, p. 69-111.

[14] Krarti M, Erickson PM, Hillman TC. A simplified method to estimate energy savings of artificial lighting use from daylighting. Building and Environment 2005; 40: 747-754.

[15] Chirarattananon S, Chaiwiwatworakul P, Pattanasethanon S. Daylight availability and models for global and diffuse horizontal illuminance and irradiance for Bangkok. Renewable Energy 2002; 26: 69-89.

[16] Lam JC, Li DHW, Cheung SO. An analysis of electricity end-use in air-conditioned office buildings in Hong Kong. Building and Environment 2003; 38(3): 493-498.

[17] Busch JF, Du Pont P, Chirarattananon S. Energy-efficient lighting in Thai commercial buildings. Energy 1993; 18: 197-210.

[18] Apian-Bennewitz P, Goller M, Herkel S, Kovach-Hebling A, Wienold J. Computer-oriented building design: Advances in daylighting and thermal simulation tools. Renewable Energy 1998; 14(1-4): 351-356.

[19] Chen YY, Liu JJ, Pei JJ, Cao XD, Chen QY, Jiang Y. Experimental and simulation study on the performance of daylighting in an industrial building and its energy saving potential. Energy and Buildings 2014; 73: 184-191.

[20] Manning MA. An experimental evaluation and comparison of four daylighting strategies for schools in North Carolina. 2006.

[21] Burton SH, Doggart J. Passive solar energy as a fuel 1990-2000. In: Sayigh AAM, editor. Energy Conservation in Buildings (The Achievement of 50\% Energy Saving: An Environmental Challenge), Pergamon Press; 1991, p. 151-156.

[22] Alrubaih MS, Zain MFM, Alghoul MA, Ibrahim NLN, Shameri MA, Elayeb O. Research and development on aspects of daylighting fundamentals. Renewable and Sustainable Energy Reviews 2013; 21: 494-505.

[23] McHugh J, Pande A, Ander G, Melnyk J. Effectiveness of photocontrols with skylighting. In: Proceeding of the IESNA Annual Conference, Tampa, Florida; 25-28 July 2004, p. 1-18.

[24] Crisp VHC, Littlefair PJ, Cooper I, McKennan G. Daylighting as a passive solar energy option: an assessment of its potential in non-domestic buildings. Building Research Establishment Report 129. Bracknell: IHS BRE Press; 1988.

[25] Xue P, Mak, CM, Cheung HD. The effects of daylighting and human behaviour on luminous comfort in residential buildings: A questionnaire survey. Building and Environment 2014; 81: 51-59.

[26] Andersen M, Gagne JML, Kleindienst S. Interactive expert support for early stage full-year daylighting design: A user's perspective on Light solve. Automation in Construction 2013; 35: 338-352.

[27] Duncan IP, Hawkes D. Passive solar design in non-domestic buildings. Report no. ETSU S-1110. Harwell: Energy Technology Support Unit; 1983.

[28] Bell J, Burt W. Designing buildings for daylight. Report 288. Bracknell: IHS BRE Press; 1995. 
[29] Littlefair P. Site layout planning for daylight and sunlight: A guide to good practice. $2^{\text {nd }}$ ed. Report 209. Bracknell: IHS BRE Press; 2011.

[30] BRE. Lighting control and daylight use. BRE Digest 272. Bracknell IHS BRE Press; 1983.

[31] CIBSE. SLL Lighting Handbook. London: CIBSE; 2009.

[32] Bodart M, De Herde A. Global energy savings in offices buildings by the use of daylighting. Energy and Buildings 2002; 34: 421-429.

[33] Doulos L, Tsangrassoulis A, Topalis F. Quantifying energy savings in daylight responsive systems: The role of dimming electronic ballasts. Energy and Buildings 2008; 40: 36-50.

[34] Ihm P, Nemri A, Krarti M. Estimation of lighting energy savings from daylighting. Building and Environment 2009; 44: 509-514.

[35] Li DHW, Cheung ACK, Chow SKH, Lee EWM. Study of daylight data and lighting energy savings for atrium corridors with lighting dimming controls. Energy and Buildings 2014; 72: 457-464.

[36] Fakra AH, Miranville F, Boyer H, Guichard S. Development of a new model to predict indoor daylighting: Integration in CODYRUN software and validation. Energy Conversion and Management 2011; 52: $2724-2734$

[37] BRE. Estimating daylight in buildings: Part 2: An aid to energy efficiency. BRE Digest 310. Bracknell: IHS BRE Press; $1986 \mathrm{~b}$.

[38] Littlefair P. Average daylight factor: a simple basis for daylight design. Information Paper 15/88. Bracknell: IHS BRE Press; 1988.

[39] Littlefair P. Measuring daylight. Information Paper 23/93. Bracknell: IHS BRE Press; 1993.

[40] Shameri MA, Alghoul MA, Elayeb O, M Zain MF, Alrubaih MS, Amir H, Sopian K. Daylighting characteristics of existing double-skin façade office buildings. Energy and Buildings 2013; 59: 279-286.

[41] Galatioto A, Beccali M. Aspects and issues of daylighting assessment: A review study. Renewable and Sustainable Energy Reviews 2016; 66: 852-860.

[42] Yu X, Su YH, Chen X. Application of RELUX simulation to investigate energy potential from daylighting in a new educational building in UK. Energy and Buildings 2014; 74: 191-202.

[43] Kittler R. Daylight prediction and assessment: Theory and Design Practice. Architectural Science Review 2007; 50(2): 94-99.

[44] Halliday A. Sustainable Construction (Chapter 9: Lighting and daylighting). Butterworth-Heinemann Ltd; 2008, ISBN: 9780750663946.

[45] DETR. Desktop guide to daylighting - for architect. Good Practice Guide 245. Watford: Building Research Energy Conservation Support Unit; 1998.

[46] Li DHW, Tsang EKW. An analysis of daylighting performance for office buildings in Hong Kong. Building and Environment 2008; 43: 1446-1458.

[47] Littlefair P, Lynes J. Design method for daylighting. Architects' Journal $7^{\text {th }}$ December 1995; 38-39.

[48] CIBSE. SLL code for lighting. London: CIBSE; 2012.

[49] CIBSE. Lighting Guide 10: Daylighting - a guide for designers. London: CIBSE; 2014. ISBN 978-1906846-48-0.

[50] Stein B, Reynolds JS. Mechanical and electrical equipment for buildings. $8^{\text {th }}$ ed. John Wiley and Sons; 1992.

[51] Poole D. How to let in the light. Architects' Journal $27^{\text {th }}$ January $1993 ; 49-50$.

[52] Love JA, Navvab M. Vertical-to-horizontal illuminance ratio: a new indocator of daylighting performance. Journal of the Illuminating Engineering Society 1994; 23(2): 50-61.

[53] CIBSE. Applications manual: window design. London: CIBSE; 1987.

[54] Littlefair P. Innovative daylighting systems. Information Paper 22/89. Bracknell: IHS BRE Press; 1989.

[55] Littlefair P. Site layout planning for daylight. Information Paper 23/12. Bracknell: IHS BRE Press; 2012.

[56] Al-Sallal KA. Sizing windows to achieve passive cooling, passive heating, and daylighting in hot arid regions. Renewable Energy 1998; 14(1-4): 365-371. 
[57] De Herde A, Nihoul A. Overheating and daylighting in commercial buildings. Renewable Energy 1994; 5 (Part II): 917-919.

[58] Saridar S, Elkadi H. The impact of applying recent façade technology on daylighting performance in buildings in eastern Mediterranean. Building and Environment 2002; 37: 1205-1212.

[59] Li DHW, Wong SL, Tsang CL, Cheung GHW. A study of the daylighting performance and energy use in heavily obstructed residential buildings via computer simulation techniques. Energy and Buildings 2006; 38: $1343-1348$.

[60] Unver R, Ozturk L, Adiguzel S, Celik O. Effect of the façade alternatives on the daylight illuminance in offices. Energy and Buildings 2003; 35: 737-746.

[61] Littlefair P. Designing with innovative daylighting. Bracknell: IHS BRE Press; 1996.

[62] Ander GD. Daylighting performance and design. John Wiley \& Sons; 2003, ISBN: 978-0-471-26299-2.

[63] Al-Obaidi KM, Abdul Rahman A.M. Toplighting systems for improving indoor environment: A review. In: Ahmad MI, Ismail M, Riffat S, editors. Renewable Energy and Sustainable technologies for Building and Environmental Applications: Options for a Greener Future, Switzerland: Springer International Publishing; 2016, p. 117-136.

[64] Cabus RC, Pereira FOR. Luminous efficacy of daylighting in intertropical region: an analysis for toplighting systems. Renewable Energy 1996; 8: 210-213.

[65] Sick F. Tageslichtnutzung (Daylighting). In: Marko A, Braun P, editors. Thermische Solaranlagen in Gebauden, Springer; 1997

[66] Tsangrassoulis A. A review of innovative daylighting systems. Advances in Building Energy Research 2008; $2: 33-56$

[67] Lim YW, Kandar MZ, Ahmad MH, Ossen DR, Abdullah AM. Building façade design for daylighting quality in typical government office building. Building and Environment 2012; 57: 194-204.

[68] Sabry H, Sherif A, Gadelhak M, Aly M. Balancing the daylighting and energy performance of solar screens in residential desert buildings: Examination of screen axial rotation and opening aspect ratio. Solar Energy 2014; 103: 364-377.

[69] Littlefair P. Solar shading of buildings. Bracknell: IHS BRE Press; 1999.

[70] Littlefair P. Developments in innovative daylighting. Bracknell: IHS BRE Press; 2000.

[71] Kim SY, Kim JJ, The impact of daylight fluctuation on a daylight dimming control system in a small office. Energy and Buildings 2007; 39: 935-944.

[72] Selkowitz S, Navvab M, Matthews S. Design and performance of light shelves. In: Proceeding International Daylighting Conference, Phoenix, AZ; 1983, p. 267-272.

[73] Bouberki M. Impact of position on the performance of a combined light shelf. In: Proceeding of the $17^{\text {th }}$ National Passive Solar Conference, ASES, San Diego CA; 1992.

[74] Aizlewood ME. Innovative daylighting systems: an experimental evaluation. Int. J. Light Res. Technol 1993; $25: 141-152$.

[75] Thomson M, Hughes A. Model Studies of daylighting factor: what are the important variables. In: Proceeding of European Conference on Energy Performance and Indoor Climate in Buildings, Lyon, France; 1994.

[76] Littlefair P. Innovative daylighting: review of systems and evaluation methods. Lighting Research and Technology 1990; 22(1): 1-17.

[77] Littlefair P. Light shelves: computer assessment of daylighting performance. Lighting Research and Technology 1995; 27: 79-91.

[78] Littlefair P, Aizlewood ME, Birtles AB. The performance of innovative daylighting systems. Renewable Energy 1994; 5(5-8): 920-934.

[79] Soler A, Oteiza P. Dependence on solar elevation of the performance of a light shelf as a potential daylighting device. Renewable Energy 1996; 8(1-5): 198-201.

[80] Evans B. Daylighting as a technology. Architects' Journal $18^{\text {th }}$ July 1996; 40-41.

[81] Smith GB, Yan W, Hossain M, McCredie G. Science of daylighting in buildings. Renewable Energy 1998; 15(1-4): 325-330. 
[82] Claros S-T, Soler A. Indoor daylight climate - comparison between light shelves and overhang performances in Madrid for hours with unit sunshine fraction and realistic values of model reflectance. Solar Energy 2001; 70(4): 233-239.

[83] Tiwari GN, Tiwari A, Shyam. Daylighting. In: Handbook of Solar Energy: Theory, Analysis and Applications. Singapore: Springer; 2016, p. 51-83.

[84] Tsangrassoulis A. Shading and Daylight Systems. Energy Performance of Buildings 2015: 437-466.

[85] Beltran LO, Lee ES, Selkowitz SE. Advanced optical daylighting systems: Light shelves and light pipes. Journal of the Illuminating Engineering Society 1997; 26(2): 91-106.

[86] Edmonds IR, Greenup PJ. Daylighting in the tropics. Solar Energy 2002; 73(2): 111-121.

[87] Chaiwiwatworakul P, Chirarattananon S. A double-pane window with enclosed horizontal slats for daylighting in buildings in the tropics. Energy and Buildings 2013; 62: 27-36.

[88] Eames PC, Norton B. A window blind reflector system for the deeper penetration of daylight into rooms without glare. Ambient Energy 1994; 25(2): 73-77.

[89] Scartezzini JL, Courret G. Anidolic daylighting systems. Solar Energy 2002; 73(2): 123-135.

[90] Laar M, Grimme FW. German developments in guidance systems: an overview daylight. Building Research \& Information 2002; 30(4): 282-301.

[91] Kazanasmaz T. Fuzzy logic model to classify effectiveness of daylighting in an office with a movable blind system. Building and Environment 2013; 69: 22-34.

[92] Tian C, Chen T, Chung T-M. Experimental and simulating examination of computer tools, Radlink and DOE2, for daylighting and energy simulation with venetian blinds. Applied Energy 2014; 124: 130-139.

[93] Howard TC, Place W, Anderson B, Coutiers P. Variable-Area Light-Reflecting Assemblies (VALRA). In: Proceedings of the $2^{\text {nd }}$ International Daylighting Conference, Long Beach, McLean VA, Cable Associates; 1986, p. 306-309.

[94] Olbina S, Beliveau Y. Developing a transparent shading device as a daylighting system. Building Research \& Information 2009; 37(2): 148-163.

[95] Moeck M. On daylight quality and quantity and its application to advanced daylight systems. Journal of the Illuminating Engineering Society 1998; 27(1): 3-21.

[96] Wilke WS, Schmid J. Modelling and simulation of elements for solar heating and daylighting. Solar Energy 1991; 46(5): 295-304.

[97] Sick F, Kummer JP. Simulation of transparently insulated buildings. Solar Energy 1992; 49(5): 429-434.

[98] Braun PO, Goetzberger A, Schmid J, Stahl W. Transparent insulation of building facades - steps from research to commercial applications. Solar Energy 1992; 49(5): 413-427.

[99] Dalenback J-O. Solar energy in building renovation. Energy and Buildings 1996; 24(1): 39-50.

[100] IEA. IEA Solar Heating and Cooling Programme: Solar Energy in Building Renovation. London: James and James Ltd; 1997.

[101] Athienitis AK, Ramadan H. Numerical Model of a building with transparent insulation. Solar Energy 1999; 67(1-3): 101-109.

[102] Voss K. Solar energy in building renovation - results and experience of international demonstration buildings. Energy and Buildings 2000; 32(3): 291-302.

[103] Wong IL, Eames PC, Perera RS. A review of transparent insulation systems and the evaluation of payback period for building applications. Solar Energy 2007; 81(9): 1058-1071.

[104] Wong IL, Eames PC. A method for calculating the solar transmittance, absorptance and reflectance of a transparent insulation system. Solar Energy 2015; 111: 418-425.

[105] Lemons TM. Lenses which improve skylight performance. In: Proceedings of International Daylighting Conference, Phoenix, Washington: AIA; 1983, p. 255-260.

[106] Edmonds IR. Performance of laser cut light deflecting panels in daylighting applications. Solar Energy Materials and Solar Cells 1993; 29(1): 1-26.

[107] Reppel J, Edmonds IR. Angle-selective glazing for radiant heat control in buildings: theory. Solar Energy 1998; 62(3): 245-253. 
[108] Edmonds IR, Pearce DJ. Enhancement of crop illuminance in high latitude greenhouses with laser-cut panel glazing. Solar Energy 1999; 66(4): 255-265.

[109] Edmonds I, Close J, Lim W, Mabb J. Daylighting street level offices in city buildings with light deflecting panels. Architectural Science Review 1998; 41(4): 173-184.

[110] Weinlader H, Beck A, Fricke J. PCM-façade-panel for daylighting and room heating. Solar Energy 2005; 78: 177-186.

[111] Arranz B, Rodriguez-Ubinas E, Bedoya-Frutos C, Vega-Sanchez S. Evaluation of three solar and daylighting control systems based on Calumen II, Ecotect and radiance simulation programmes to obtain an energy efficient and heathy interior in the experimental building Prototype SD10. Energy and Buildings 2014; 83: 225-236.

[112] Sharp F, Lindsey D, Dols J, Coker J. The use and environmental impact of daylighting. Journal of Cleaner Production 2014; 85: 462-471.

[113] Poole D. Low-energy factories, 4 Daylighting. Architects' Journal 30 ${ }^{\text {th }}$ May 1990; 63-65.

[114] McDowell A, Sedgwick A, Lenczner A. Shedding light on the Louvre. Architects' Journal $27^{\text {th }}$ April 1994; 29-31.

[115] Galasiu AD, Atif MR. Applicability of daylighting computer modelling in real case studies: comparison between measured and simulated daylight availability and lighting consumption. Building and Environment 2002; 37: 363-377.

[116] Kim CS, Chung SJ. Daylighting simulation as an architectural design process in museums installed with toplights. Building and Environment 2011; 46: 210-222.

[117] National Association of Rooflight Manufacturers. An introduction to natural daylight design through rooflighting. NARM Technical Document NTD01.2. Milton Keynes: NARM; 2014.

[118] Acosta I, Navarro J, Sendra JJ. Daylighting design with lightscoop skylights: Towards an optimisation of shape under overcast sky conditions. Energy and Buildings 2013; 60: 232-238.

[119] Mardaljevic J, Lomas K. Daylighting and solar analysis for rooflights: Resolving the perceived conflict in Part L Recommendations. Milton Keynes: National Association of Rooflight Manufacturers; 2003.

[120] Kotani H, Narasaki M, Sato R, Yamanaka T. Environmental assessment of light well in high-rise apartment building. Building and Environment 2003; 38(2): 283-289.

[121] Cheung HD, Chung TM. Calculation of the vertical daylight factor on window facades in a dense urban environment. Architectural Science Review 2005; 48(1): 81-92.

[122] Kim JT, Kim G. Overview and new developments in optical daylighting systems for building a healthy indoor environment. Building and Environment 2010; 45: 256-269.

[123] Rogora A, Palermo G. New component for daylighting: first Italian application of a sun duct. Renewable Energy 1994; 5: 974-976.

[124] Francini F, Fontani D, Sansoni P. Transport of light by optical fibers and light pipes. In: Sansoni P, Mercatelli L, Farini A, editors. Sustainable Indoor Lighting, London: Springer; 2015, p. 195-210.

[125] Chirarattananon S, Chedsiri S, Renshen L. Daylighting through light pipes in the tropics. Solar Energy 2000; 69(4): 331-341.

[126] Edmonds IR, Moore GI, Smith GB, Swift PD. Daylighting enhancement with light pipes coupled to laser-cut light-deflecting panels. Light Research and Technology 1995; 27(1): 27-35.

[127] Elmualim AA, Smith S, Riffat SB, Shao L. Evaluation of dichroic material for enhancing light pipe/ natural ventilation and daylighting in an integrated system. Applied Energy 1999; 62(4): 253-266.

[128] Garcia-Hansen V, Edmonds IR, Hyde R. The use of light pipes for deep plan office buildings - a case study of Ken Yeang's bioclimatic skyscraper proposal for KLCC, Malaysia. In: Proceeding of the $35^{\text {th }}$ Annual Conference of the Australia and New Zealand Architectural Science Association - ComputerMediated Reality: Crafting Design Quality, Wellington, New Zealand; 2001.

[129] Jenkins D, Munner T. Modelling light-pipe performance - a natural daylighting solution. Building and Environment 2003; 38(7): 965-972.

[130] West S. Improving the sustainable development of building stock by the implementation of energy efficient, climate control technologies. Building and Environment 2001; 36(3): 281-289.

[131] Shao L, Callow JM. Daylighting performance of optical rods. Solar Energy 2003; 75: 439-445. 
[132] Ullah I, Shin S. Highly concentrated optical fiber-based daylighting systems for multi-floor office buildings. Energy and Buildings 2014; 72: 246-261.

[133] Venturi L. Light piping performance enhancement using a deflecting sheet. Lighting Research and Technology 2006; 38(2): 167-179.

[134] Sedki L, Maaroufi M. Performance assessment of installed low cost solar daylighting system via optical fiber. Energy Engineering 2017; 114(2): 37-55.

[135] Edmonds IR, Reppel J, Jardine P. Extractors and emitters for light distribution from hollow light guides. Lighting Research and Technology 1997; 29(1): 23-32.

[136] Compagnon R, Scartezzini J-L, Paule B. Application of non-imaging optics to the development of new daylighting systems. In: Proceeding of ISES World Congress, Budapest, Hungary; 1993.

[137] Courret G, Scartezzini J-L, Francioli D, Meyer J-J. Design and assessment of an anidolic light-duct. Energy and Buildings 1998; 28(1): 79-99.

[138] Kischkoweit-Lopin M. An overview of daylighting systems. Solar Energy 2002; 73(2): 77-82.

[139] Molteni SC, Courret G, Paule B, Michel L, Scartezzini JL. Design of anidolic zenithal lightguides for daylighting of underground spaces. Solar Energy 2001; 69(1-6): 117-129.

[140] Vazquez-Molini D, Gonzalez-Montes M, Fernandez-Balbuena AA, Garcia-Botella A, Pohl W, Galan T, Bernabeu E. Horizontal daylighting system for office buildings. Energy and Buildings 2013; 67: 525-530.

[141] Page J, Scartezzini J-L, Kaempf J, Morel N. On-site performance of electrochromic glazings coupled to an anidolic daylighting system. Solar Energy 2007; 81: 1166-1179.

[142] Mohelnikova J, Vajkay F. Daylight simulations and tubular light guides. International Journal of Sustainable Energy 2008; 27(3): 155-163.

[143] Katz D. Daylight harvesting technologies. Energy Engineering 2005; 102(1): 40-48.

[144] Aghemo C, Pellegrino A, LoVerso VRM. The approach to daylighting by scale models and sun and sky simulators: A case study for different shading systems. Building and Environment 2008; 43: 917-927.

[145] Zastrow A, Wittwer V. Daylighting with mirror light pipes and with fluorescent planar concentrators. First results from the Demonstration Project Stuttgart - Hohenheim. In: Proceeding of SPIE 0692, Materials and Optics for Solar Energy Conversion and Advanced Lightning Technology, 227 (February 23, 1987); 1987.

[146] Swift PD, Smith GB. Cylindrical mirror light pipes. Solar Energy Materials and Solar Cells 1995; 36(2): 159-168.

[147] Zhang X, Muneer T. A mathematical model for the performance of light pipes. Lighting Research and Technology 2000; 32(3): 141-146.

[148] Zhang X, Muneer T, Kubie J. A design guide for performance assessment of solar light-pipes. Lighting Research and Technology 2002; 34(2): 149-168.

[149] Dutton S, Shao L. Raytracing simulation for predicting light pipe transmittance. International Journal of Low-Carbon Technologies 2007; 2(4): 339-358.

[150] Gagne JML, Andersen M, Norford LK. An interactive expert system for daylighting design exploration. Building and Environment 2011; 46(11): 2351-2364.

[151] Jovanovic A, Pejic P, Djoric-Veljkovic S, Karamarkovic J, Djelic M. Importance of building orientation in determining daylighting quality in student dorm rooms: Physical and simulated daylighting parameters' values compared to subjective survey results. Energy and Buildings 2014; 77: 158-170.

[152] Kota S, Haberl JS, Clayton MJ, Yan W. Building Information Modeling (BIM)-Based Daylighting Simulation and Analysis. Energy and Buildings 2014; 81: 391-403.

[153] Kruger EL, Dorigo AL. Daylighting analysis in a public school in Curitiba, Brazil. Renewable Energy 2008; 33: 1695-1702.

[154] Loutzenhiser PG, Maxwell GM, Manz H. An empirical validation of the daylighting algorithms and associated interactions in building energy simulation programs using various shading devices and windows. Energy 2007; 32: 1855-1870.

[155] Ward G. The RADIANCE Lighting Simulation and Rendering System. In: Computer Graphics Proceedings, Annual Conference Series; 1994. 
[156] Ochoa CE, Aries MBC, Hensen JLM. State of the art in lighting simulation for building science: a literature review. Journal of Building Performance Simulation 2012; 5(4): 209-233.

[157] Bodart M, Deneyer A, De Herde A, Wouters P. A guide for building daylight scale models. Architectural Science Review 2007; 50(1): 31-36.

[158] Kittler R, Kocifaj M, Darula S. Daylight Science and Daylighting Technology, London: Springer; 2012.

[159] Ashmore J, Richens P. Computer simulation in daylight design: a comparison. Architectural Science Review 2001; 44(1): 33-44.

[160] Gibson T, Krarti M. Comparative analysis of prediction accuracy from daylighting simulation tools. LEUKOS (The Journal of the Illuminating Engineering Society of North America 2015; 11(2): 49-60.

[161] Reinhart C, Fitz A. Findings from a survey on the current use of daylight simulations in building design. Energy and Buildings 2006; 38: 824-835.

[162] Laouadi A, Coffey B. The energy performance of the central sunlighting system. Journal of Building Performance Simulation 2012; 5(4): 234-247.

[163] Mayhoub MS. Innovative daylighting systems' challenges: A critical study. Energy and Buildings 2014; 80: 394-405.

[164] Lam JC, Li DHW, Yuen RKK. An analysis of daylighting energy performance using computer simulation techniques. Architectural Science Review 1998; 41(4): 145-155. 